This item was submitted to Loughborough's Research Repository by the author.

Items in Figshare are protected by copyright, with all rights reserved, unless otherwise indicated.

\title{
Monitoring anaerobic digestion: a 2-year brewery case study
}

PLEASE CITE THE PUBLISHED VERSION

http://dx.doi.org/10.1680/jees.14.00008

PUBLISHER

(C) ICE Publishing

VERSION

VoR (Version of Record)

\section{PUBLISHER STATEMENT}

This work is made available according to the conditions of the Creative Commons Attribution-NonCommercialNoDerivatives 4.0 International (CC BY-NC-ND 4.0) licence. Full details of this licence are available at: https://creativecommons.org/licenses/by-nc-nd/4.0/

\section{LICENCE}

CC BY-NC-ND 4.0

\section{REPOSITORY RECORD}

Radu, Tanja, Richard Blanchard, Vincent Smedley, Helen Theaker, and Andrew D. Wheatley. 2015. "Monitoring Anaerobic Digestion: A 2-year Brewery Case Study". Loughborough University. https://hdl.handle.net/2134/17643. 
Journal of Environmental Engineering and Science

Volume 9 Issue JS4

Monitoring anaerobic digestion: a 2-year brewery case study

Radu, Blanchard, Smedley, Theaker and

Wheatley
Journal of Environmental Engineering and Science, 2014, 9(4), 207-213 http://dx.doi.org/10.1680/jees. 14.00008 Paper 14.00008

Received 09/06/2014; accepted 13/11/2014

Published online 09/12/2014

Keywords: renewable energy/research \& development/waste management \& disposal

ICE Publishing: All rights reserved

\section{Monitoring anaerobic digestion: a 2-year brewery case study}

1 Tanja Radu BSC, MCE, PhD, AFHEA Research Associate, School of Civil and Building Engineering, Loughborough University, Loughborough, United Kingdom

2 Richard Blanchard BSC, PhD, PGCE, FHEA, AIEMA Lecturer in Renewable Energy, School of Electronic, Electrical and Systems Engineering, Loughborough University, Loughborough, United Kingdom

3 Vincent Smedley BSC, MEng School of Civil and Building Engineering, Loughborough University, Loughborough, United Kingdom
4 Helen Theaker BSC, MSC Unilever UK Ltd, Burton-upon-Trent, United Kingdom

5 Andrew Wheatley BSC, PhD

Professor, School of Civil and Building Engineering, Loughborough University, Loughborough, United Kingdom
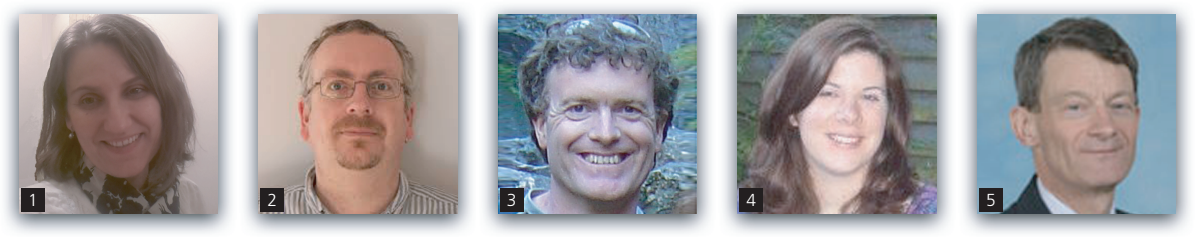

Operational data from an anaerobic wastewater treatment plant (expanded granular sludge bed (EGSB) reactor) were analysed before and after a defect with the solids separator. The results presented suggest that a newly available method for the analysis of total volatile fatty acids (VFAs) was ideal as a rapid, onsite, operational indicator of reactor stability. These total VFAs were shown to provide an earlier warning of the separator problem than the other rapid routine methods of monitoring digesters such as alkalinity and suspended solids. Chemical oxygen demand (COD) removal, $\mathrm{pH}$ and gas yield were not as useful for monitoring because of their slow response. The results are from a high rate reactor; the loads were $18 \mathrm{~kg} \mathrm{COD} / \mathrm{m}^{3} / \mathrm{d}$ in the first year and 26 in the second with $4.4 \mathrm{~d}$ hydraulic retention time. The results for both years of operation demonstrate a $95 \%$ conversion of COD into gas with an additional contribution from solids digestion (specific gas yield of $0.4 \mathrm{I}$ methane $\left.\left(\mathrm{CH}_{4}\right) / \mathrm{g} C O \mathrm{D}_{\text {rem }}\right)$. This high performance was attributed to the solubility of the COD and the efficient EGSB mixing.

\section{Introduction}

The treatment of brewery wastewater is the most common application of high-rate anaerobic digestion (AD) of wastewaters. Because of the large volumes and strengths of brewery wastewater effluent and also their high biodegradability, regulatory authorities often insist on treatment before discharge to sewer to avoid overloading the sewer and treatment system. Specific water consumption of breweries ranges from 4 to 111 water per litre of beer, with two thirds of the water being used for production and one third for cleaning processes (Fillaudeau et al., 2006). A review of brewery wastewater literature gave a chemical oxygen demand (COD) range of between 1200 and $125000 \mathrm{mg} / \mathrm{l}$ COD (Baloch et al., 2007; Leal et al., 1998). The wide range of COD values is due to the batch production, seasonality and variety of process streams included such as brewing, malting, spent grains and other wash waters (Kato et al., 1999). The effluent usually has a high biological oxygen demand (BOD)-to-COD ratio or a high biodegradability, as a result of the dissolved carbohydrates and alcohol. Less attention has been paid to the suspended solids (SS) and values between 1550 and $1750 \mathrm{mg} / \mathrm{l}$ (Baloch et al., 2007) are reported. Comparisons are made difficult since the SS are variously expressed as total, settleable and suspended, sometimes corrected for volatile solids.

For this type of medium- to high-strength food and drinks wastewater, traditional aerobic treatment has become expensive as a result of power for aeration and the high sludge yields (Parawira et al., 2005). Thus, anaerobic treatment with lower running costs and added value from financial support mechanisms for renewable energies has become more attractive. These incentives have overcome the higher investment costs, lack of experience and reputation for instability (Franklin 2001; Lettinga, 1995; Parawira 
et al., 2005). The solubility and resulting high biodegradability, together with the large variations in waste characteristics, present risks to the stability of the slower anaerobic process (Cronin and Lo, 1998; Leal et al., 1998). A recent survey of operating AD plants in the EU noted that excess acidity from shock loads was the most common cause of stability problems (Chen et al., 2008).

The anaerobic digester in the study was the widely used and studied expanded granular sludge bed (EGSB) (Ahn et al., 2001; Alphenaar et al., 1993; Franklin, 2001; Gonzalez et al., 1998; Goodwin et al., 2001; Fuentes et al., 2011). The EGSB process relies on a rapidly settling (Lettinga et al., 1983), granulated biomass to uncouple solids retention from hydraulic flow. Zoutberg and de Been (1997), for example, reported liquid velocities of $15 \mathrm{~m} / \mathrm{h}$ were achievable with granular biomass, compared with $1 \mathrm{~m} / \mathrm{h}$ for flocculated biomass and internal solids/liquid separation is normal with these types of bioreactors (Figure 1). Biomass expansion by both gas and hydraulic forces improves mass transfer as in fluidised bed bioreactors and so increases reactor efficiency (Franklin, 2001). However, this process flushes out fine solids otherwise retained, potentially limiting their performance if the effluent contains fine solids, as in this case study (yeast), or if the granules are unstable. Therefore, performance monitoring remains a crucial part of judging the stability of these reactors.

In this paper, we report on these variations and potential monitoring strategies from 2 years of operational performance from the anaerobic treatment of a brewery type waste before and after failure of the internal separator.

\section{Materials and methods}

The Marmite AD plant was commissioned in 2008; it is part of a three-stage sequential process, as shown in Figure 1.

Process wastewater drains from various parts of the factory by gravity to two subterranean collection tanks (total capacity, $50 \mathrm{~m}^{3}$ ) via a simple $10-\mathrm{mm}$ inclined screen to intercept packaging and/or other debris. Effluent is then pumped to the $400-\mathrm{m}^{3}$ buffering tank (Figure 1). Typically, the buffering tank will run half full to ensure mixing of different strengths and compositions and avoid shocks to the $\mathrm{AD}$ culture. Further buffering is provided by the conditioning tank (Figure 1), which recycles treated effluent to buffer and dilutes the feed. It has a volume of $28 \mathrm{~m}^{3}$ and a recycle rate of $200 \mathrm{~m}^{3} / \mathrm{h}$ 10:1 recycle to feed. Acid, alkali and steam can be introduced into this tank to maintain temperature $\left(35^{\circ} \mathrm{C}\right)$ and $\mathrm{pH}(7)$ if necessary.

The anaerobic reactor is a $900-\mathrm{m}^{3}$ EGSB BioThane design that includes a three-phase separator (biogas, liquid and solids) to help with granule retention (Latif et al., 2011).

The height of the sludge bed can be measured with sampling taps and typically occupies two thirds of the reactor (Figure 1). Gas generated from the EGSB is used in the factory boilers or flared when in excess. The boiler biogas is cooled (refrigerated heat

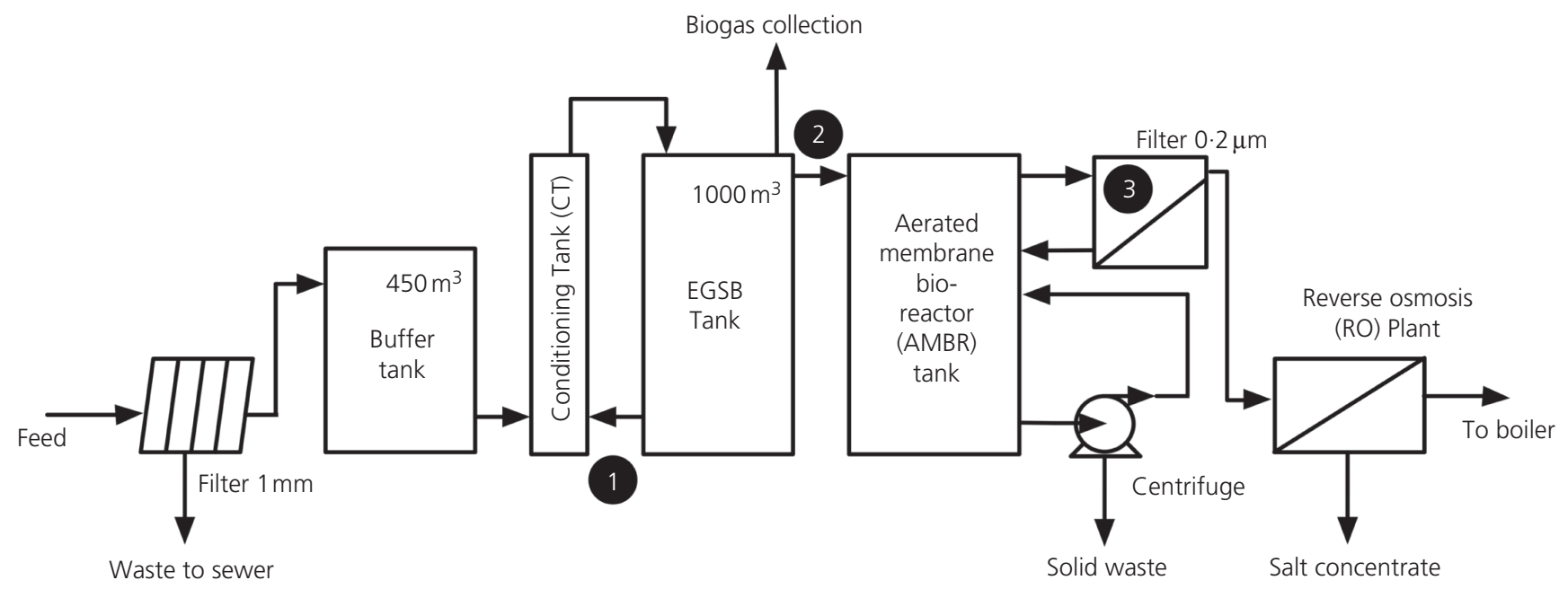

\footnotetext{
(1) Feedstock circulated round conditioning tank (CT) and expanded granular sludge blanket (EGSB) tank

2 Digestate removed from the EGSB tank

3 Membrane filter passes filtered water to the reverse osmosis (RO) plant
} 


\section{Offprint provided courtesy of www.icevirtuallibrary.com} Author copy for personal use, not for distribution

exchanger) to remove water vapour and then wet scrubbed with sodium hydroxide in a counter current stripping tower to remove sulphides. The gas is then pressurised and fed into one of the existing boilers (modified with ceramic burners).

The aerobic reactor (stage 2) is a membrane bioreactor (MBR) designed by Aquabio. It uses an external cross flow hollow fibre membrane pore size $0 \cdot 2 \mu \mathrm{m}$. Mixed liquor is recirculated via the membranes and reinjected into the MBR tank via a Venturi where the compressed air is injected (Figure 1). The excess biosolids from the membranes are concentrated by centrifuge and reused in agriculture.

MBR-treated effluent can then be further purified by reverse osmosis. This system produces ultra-pure boiler feed water for cleaning but is not used in food production.

\section{Monitoring}

The wastewater treatment includes automatic adjustment of $\mathrm{pH}$ and temperature, although the warm effluent and recirculation minimises these interventions. Manual adjustments in special circumstances are occasionally needed, for example, high buffer tank levels, but more routinely to avoid overload. This has been monitored routinely two to four times a day by a loss in alkalinity (Ripley's ratio, referred to as intermediate to partial alkalinity in the standard methods). Total and filtered COD, SS, Ripley's ratio and volatile fatty acids (VFAs) are analysed daily. Flow rate, $\mathrm{pH}$, and biogas flow are recorded continuously. The biomass level in the reactor is checked weekly, while biomass total and volatile solids (TS and VS) and biogas composition are checked monthly.

The wet analysis was carried out in accordance with the international standard methods in this case to APHA (2005) using Hach preprepared reagents. VFAs are common stability indicators because they are metabolic intermediates, and if the methanogenesis is failing to cope with the fluctuations in load, they rapidly accumulate, suppressing methane production even when not detectable from a pH change (Baloch et al., 2007). Gas chromatography or distillation is the standard method of determination of VFAs (APHA, 2005) but is too time consuming for practical monitoring of the potential harm caused by the daily fluctuations in organic load when operating at low hydraulic retention time (HRT). Chromatography also gives quantitative data on the individual VFA that enables research on the causes of upsets other than overloading. Total or partial alkalinity is a low-cost, operational alternative. In this case, the Ripley ratio was used to represent the amount of VFAs to alkalinity. It can be carried out more quickly and with simple equipment compared with other alkalinity measures. A ratio below $0 \cdot 3$ is considered an acceptable value, but for an $\mathrm{AD}$ plant that is monitored daily, an indicator value of up to $0 \cdot 5$ can be used to signal action that needs to be taken to address the problem.

A simple colorimetry-based VFA test kit became available during the commissioning of the plant; this was the Hach LCK 365 method. It is based on forming iron-coloured esters and takes about
15 min, thus simplifying the VFA analysis and making it costeffective. This made it possible to compare the performance of Ripley's ratio with VFA content for the daily operational control of the loading rate.

\section{Results and discussion}

Towards the end of the first year (day 275), an increase in VFA was noticed, with a smaller increase in Ripley's ratio and some solids loses (Figure 2). The opportunity was taken during the annual shut down of the factory for inspection of the EGSB, at $340 \mathrm{~d}$, which revealed damage to the gas liquid separator. This necessitated a further planned shutdown (days 400-450) for repairs.

Both VFA and Ripley's ratio were sensitive to these problems and demonstrate the differences in stability between year 1 and 2 (Figure 2). Figure 2 suggests that the VFA gave earlier warning than Ripley's of the problem and that it was more pronounced. During the first year of operation, the average Ripley's ratio of the reactor was $0 \cdot 4$ (Table 1 , range $0 \cdot 2-1 \cdot 04$ ); corresponding VFA values were in the range $52-2488 \mathrm{ppm}$ (January-December) suggesting greater sensitivity than Ripley's (Table 1). During the period before the shutdown, VFA exceeded $1000 \mathrm{ppm}$ several times, but the reactor $\mathrm{pH}$ did not drop below 7. Thus, it was concluded, as it has been previously, that $\mathrm{pH}$ values are not a suitable indicator for controlling these high-rate digesters. Lower biogas production and COD removal was not apparent until day 395 when Ripley's ratio was 1·88.

Following the restart, the digester Ripley's ratio for year 2 had an average value of $0 \cdot 29$, while VFAs were below $100 \mathrm{mg} / 1$ (Table 1), indicating greater reactor stability. The data in Figure 2 also led to the conclusion that total VFAs, when easy to carry out, would be an earlier indicator of reactor instability than alkalinity. We expect this based on Ripley's being a ratio of alkalinity and VFAs. A VFA increase before Ripley's ratio would be anticipated in situations where there is high alkalinity, which also increases with load to dampen the response, for example, animal slurry and sewage sludge. Goodwin et al. (2001) have reported operating data from a stressed upflow anaerobic sludge blanket (UASB) reactor when treating whisky distillery pot ale. A simultaneous increase in COD and reduction in HRT led to VFA concentrations of nearly $20 \mathrm{~g} / \mathrm{l}$ and decreased biogas production, while $\mathrm{pH}$ levels stayed above 7 despite the almost complete reactor failure. Bocher et al. (2008) also reported that a shock increase in loading rate and decrease in HRT caused an increase in VFAs, leading to instability of the reactor. Bocher et al. (2008) also noted foam formation, which caused biomass losses and decreased activity. Both these papers imply that insufficient mixing was the possible cause of failure in their UASB. In the case of the EGSB expanded by recycling, we expect mixing to be thorough, although solids losses as a result of gas surges are a possibility. Prior to the repairs to the gas liquid separator, total suspended solids (TSS) removal was 20\% and variable although HRT was constant (Figure 2). Following the repairs, overall TSS removal efficiency was still low at $\sim 30 \%$, and as previously noted, EGSB reactors would not be expected to retain fine solids because of vigorous mixing (Zoutberg and de Been, 

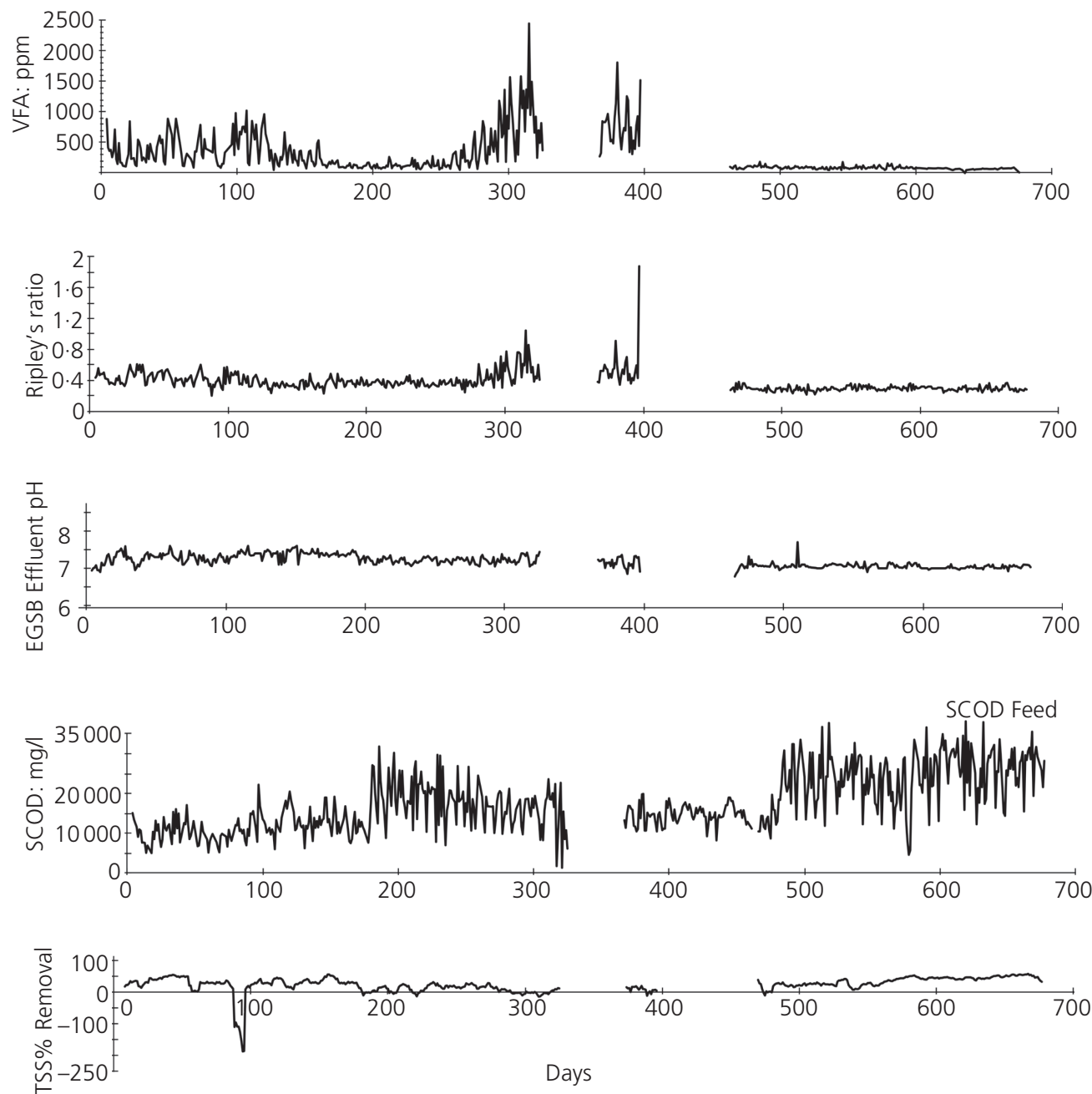

Figure 2. Overview of ESGB performance for time period of study

1997). There are limited operational publications on solids retention or liquid and gas velocities but Parawira et al. (2005) reported total solids removal of below $40 \%$ for their UASB reactor, which was improved to $60 \%$ to $80 \%$ by the introduction of a $0 \cdot 5-\mathrm{mm}$ screen. Mixing in UASB compared with EGSB reactors, on the other hand, is lower and generates better solids retention. Cronin and Lo (1998) noted VSS reduction of $81 \%$; Parawira et al. (2005), 90\% for settleable solids; and Bocher et al. (2008), 43\% but as VS rather than SS removal efficiency. Lettinga (1995), Franklin (2001) and Bocher et al. (2008) have suggested that good mixing between substrate and biomass in EGSB reactors is the reason for their good performance, and effluent COD values less than $1 \mathrm{~g} / 1$ are normal. Cronin and Lo (1998) and Borja et al. (1994) found increasing the organic loading rate (OLR) by reducing the HRT from 10 to $1 \cdot 2 \mathrm{~d}$ only reduced COD removal from $98.5 \%$ (HRT of $10 \mathrm{~d}$ ) to $95 \cdot 4 \%$ (HRT of $1 \cdot 2 \mathrm{~d}$ ). HRT in this EGSB study was fixed by the recycle loop to $4.4 \mathrm{~d}$ equivalent with an upflow liquid velocity of $3.7 \mathrm{~m} / \mathrm{h}$. Average gas velocities were $1.2 \mathrm{~m} / \mathrm{h}$ in year 1 and $1.8 \mathrm{~m} / \mathrm{h}$ in year 2 . Actual mixing velocities and granule losses are less well reported. Calculations of velocities through the separator passages could also be a useful indicator of the potential for solids losses (Fuentes et al., 2011), but we also note from Figure 2 that although SS (TSS) balance could be a better stability indicator than $\mathrm{pH}, \mathrm{COD}$ removal or gas production, it was not very sensitive compared with alkalinity of VFA.

The variability in feed COD meant that deterioration in COD conversion to gas was difficult to spot. The range of TCOD of the buffered wastewater was between 5500 and $41400 \mathrm{mg} / \mathrm{l}$, in the range previously reported (Baloch et al., 2007; Parawira et al., 2005) and gave typical EGSB OLR, which are between 10 and $30 \mathrm{~kg} \mathrm{COD} / \mathrm{m}^{3} / \mathrm{d}$ (Baloch et al., 2007; Franklin, 2001; Kato et al., 1999; Zoutberg and de Been, 1997). The average OLR was $18 \mathrm{~kg} \mathrm{COD} / \mathrm{m}^{3} / \mathrm{d}$ in year 1 and $26 \mathrm{~kg} \mathrm{COD} / \mathrm{m}^{3} / \mathrm{d}$ in year 2 . COD removal was $88 \%$ in year 1 and $95 \%$ in year 2 (Table 1, Figure 2).

Other published work on the treatment of brewery waste include Baloch et al. (2007) (93-96\% COD removal with a EGSB at 


\section{Offprint provided courtesy of www.icevirtuallibrary.com Author copy for personal use, not for distribution}

\begin{tabular}{|c|c|c|c|c|c|}
\hline & & \multicolumn{2}{|c|}{ Buffered waste water } & \multicolumn{2}{|c|}{ Reactor effluent } \\
\hline & & P1 (0-320 days) & P2 (470+ days) & P1 (0-320 days) & P2 (470+ days) \\
\hline \multirow[t]{2}{*}{ COD: mg/l } & Average & 18256 & 25981 & $2184 \cdot 62$ & $1216 \cdot 15$ \\
\hline & SD & $6019 \cdot 2$ & $7150 \cdot 2$ & $649 \cdot 37$ & $396 \cdot 36$ \\
\hline \multirow[t]{2}{*}{ SCOD: mg/l } & Average & $14317 \cdot 25$ & $24040 \cdot 61$ & 647 & 238 \\
\hline & SD & $5488 \cdot 55$ & 6882.97 & $455 \cdot 5$ & $51 \cdot 5$ \\
\hline \multirow[t]{2}{*}{ COD load: kg/m³/day } & Average & $18 \cdot 29$ & $25 \cdot 73$ & & \\
\hline & SD & 6.02 & 7.44 & & \\
\hline \multirow[t]{2}{*}{ TSS: mg/l } & Average & $2099 \cdot 39$ & $1511 \cdot 70$ & $1720 \cdot 48$ & $1024 \cdot 10$ \\
\hline & SD & $625 \cdot 93$ & $444 \cdot 39$ & $1262 \cdot 68$ & 371.65 \\
\hline \multirow[t]{2}{*}{$\mathrm{pH}$} & Average & $6 \cdot 57$ & $6 \cdot 15$ & $7 \cdot 27$ & $7 \cdot 05$ \\
\hline & SD & 0.93 & 0.94 & $0 \cdot 14$ & 0.07 \\
\hline \multirow[t]{2}{*}{ VFA } & Average & & & $352 \cdot 60$ & $86 \cdot 74$ \\
\hline & SD & & & $327 \cdot 29$ & $24 \cdot 23$ \\
\hline \multirow[t]{2}{*}{ Ripley's ratio } & Average & & & 0.41 & 0.29 \\
\hline & SD & & & 0.13 & 0.03 \\
\hline Biogas production: & Average & & & $2287 \cdot 70$ & $3542 \cdot 46$ \\
\hline $\mathrm{Nm}^{3} /$ day & SD & & & $901 \cdot 24$ & $1191 \cdot 70$ \\
\hline Biogass production: & Average & & & 0.58 & 0.57 \\
\hline $\mathrm{m}^{3} / \mathrm{kg}$ TCOD removed & SD & & & $0 \cdot 13$ & $0 \cdot 10$ \\
\hline \multicolumn{6}{|c|}{$\begin{array}{l}\text { Table 1. Summary of the key performance parameters for } \\
\text { the buffered wastewater and the reactor effluent, for periods } \\
\text { pre-shutdown (P1, days } 0-320) \text { and post-shutdown } \\
\text { (P2, days } 470+\text { ) }\end{array}$} \\
\hline
\end{tabular}

2-13 kg COD $\left./ \mathrm{m}^{3} / \mathrm{d}\right)$ and Leal et al. (1998) (96\% COD removal using an anaerobic filter at $8 \mathrm{~kg} \mathrm{COD} / \mathrm{m}^{3} / \mathrm{d}$ loading rate). Zheng et al. (2012) found that increasing the OLR from 15 to $45 \mathrm{~kg}$ $\mathrm{COD} / \mathrm{m}^{3} / \mathrm{d}$ with an EGSB increased the COD removal efficiency from $92 \cdot 1 \%$ to $97 \cdot 2 \%$, possibly by improving mixing, but this was not investigated.

Efficient COD conversion to gas can also be attributed to the high proportion of soluble COD (SCOD) in many food-processing effluents, for example, sugar and alcohols. Values greater than $90 \%$ COD removal are commonly reported in the literature when there is high solubility and therefore biodegradability (Baloch et al., 2007; Borja et al., 1994; Connaughton et al., 2006; Cronin and Lo, 1998; Gonzalez et al., 1998; Leal et al., 1998; Zheng et al., 2012). Ahn et al. (2001) reported a 76\% soluble fraction for brewery waste, and Goodwin et al. (2001) reported 78-84\% solubility from whisky distillery pot ale. Average SCOD in this case study was $84 \cdot 5 \% \pm 10 \cdot 6 \%$. SCOD reduces the time for hydrolysis, a rate-limiting step. The SCOD removal efficiency was $95 \%$ in year 1 and, following the separator repairs, $98 \%$ in year 2 (Figure 2, Table 1). Gas production would be expected to be linked to SCOD removal, suggested by Figure 3, showing a linear correlation $\left(R^{2}=0 \cdot 87\right)$. Baloch et al. (2007) reported increases in gas production with load, and Zheng et al. (2012) showed a doubling of gas production when the OLR increased from 20 to $40 \mathrm{~kg} \mathrm{COD} / \mathrm{m}^{3} / \mathrm{d}$.
Gas production was corrected for pressure and temperature in order to give the specific gas yield per $\mathrm{kg}$ of COD removed. There was an average of $0.41 \mathrm{CH}_{4} / \mathrm{g}$ COD removed. This exceeds the stoichiometric value of $0.35 \mathrm{~m}^{3} / \mathrm{kg}$ COD removed from a carbohydrate feedstock, and this was attributed to the solids conversion. It was also higher than previous work on brewery effluents. Connaughton et al. (2006), for example, reported $0 \cdot 28 \mathrm{~m}^{3} \mathrm{CH}_{4} / \mathrm{kg}$ COD removed, from a hybrid EGSB-anaerobic filter; Cronin and Lo (1998) reported $0 \cdot 30-0 \cdot 34 \mathrm{~m}^{3} \mathrm{CH}_{4} / \mathrm{kg}$ COD removed using a UASB reactor; and Ahn et al. (2001) reported $0.35 \mathrm{~m}^{3} / \mathrm{kg}$ COD removed for UASB. These differences are attributed to the differences in solids mass balances, which are not always reported.

There is also literature on gas quality, and in this study, methane concentration was $70 \% \pm 9 \%$ higher than the $60-62 \%$ methane from brewery effluent reported by Van Der Merwe and Britz (1993) and Bocher et al. (2008) but similar to Baloch et al. (2007), 62\% to $75 \%$, and lower than Leal et al. (1998), who reported $80-95 \%$ methane from brewery wastewater, suggesting that more data are needed on methane measurements.

\section{Conclusions and recommendations}

Total VFA analysis using the new colorimetric test kit followed by Ripley's ratio is a simple monitoring technique suitable for operational control and early warnings of instability for high-rate 


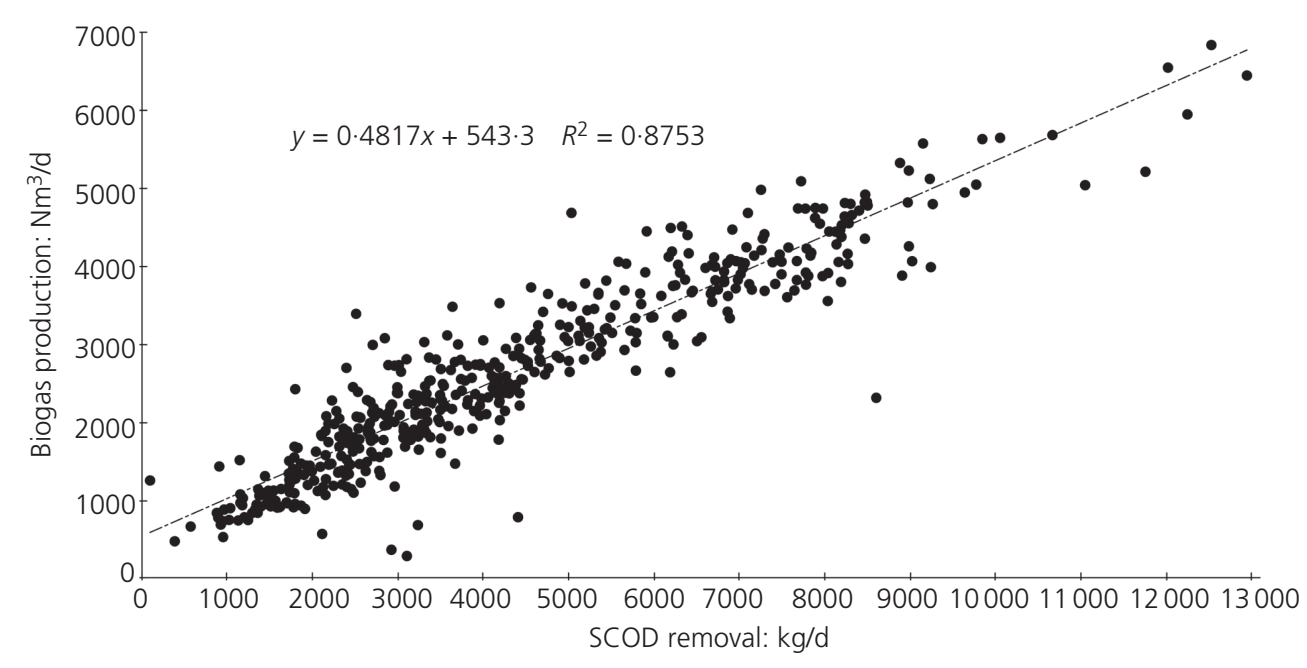

Figure 3. Correlation between biogas production and SCOD

removal. Gas continues to be produced because of the $4 \mathrm{~d}$ retention time and retains solids digestion; hence, the correlation line does not pass through the origin.

EGSB digesters. COD conversion to gas or $\mathrm{pH}$ was not an effective test for instability.

There was no evidence of granule losses as a result of the damage to the internal separator, but SS measurements are needed in order to understand mass balances and interpret specific gas yields. Standard reporting of liquid and gas velocities would also help compare solids losses from gas surges or other hydraulic perturbations that could otherwise be converted to gas.

The results reported here confirm the need for effluent buffering, as the range of in-flow rate was $12-774 \mathrm{~m}^{3} / \mathrm{d}$, COD in the raw effluent ranged from 5500 to $41400 \mathrm{mg} / \mathrm{l}$, and total SS values were between 260 and $4800 \mathrm{mg} / \mathrm{l}$. These variations were reflected in reactor stability and performance; they were typical of previous works on brewery effluents.

Anaerobic conversion of COD to gas was linked to its solubility, in this case achieving a greater than $95 \%$ conversion at $20 \mathrm{~kg}$ $\mathrm{COD} / \mathrm{m}^{3} / \mathrm{d}$.

\section{Acknowledgements}

This research is funded by the Engineering and Physical Sciences Research Council (EPSRC) under EP/J000361/1 Rural Hybrid Energy Enterprise Systems (RHEES) project. The authors would like to extend their thanks to the staff of Unilever Marmite AD Plant for their time and valuable advice.

\section{REFERENCES}

Ahn Y, Min K and Speece RE (2001) Pre-acidification in anaerobic sludge bed process treating brewery wastewater. Water Research 35(18): 4267-4276.
Alphenaar PA, Visser A and Lettinga G (1993) The effect of liquid upward velocity and hydraulic retention time on granulation in UASB reactors treating wastewater with a high sulphate content. Bioresource Technology 43: 249-258.

APHA (2005) Standard Methods for the Examination of Water and Wastewater, 21st edn. American Public Health Association, Washington, DC, USA.

Baloch MI, Akunna JC and Collier PJ (2007) The performance of a phase separated granular bed bioreactor treating brewery wastewater. Bioresource Technology 98: 1849-1855.

Bocher BT, Agler MT, Garcia ML, Beers AR and Angenent LT (2008) Anaerobic digestion of secondary residuals from an anaerobic bioreactor at a brewery to enhance bioenergy generation. Journal of Industrial Microbiology and Technology 35: 321-329.

Borja R, Martin A, Durin MM, Luquea M and Alonso V (1994) Kinetic study of anaerobic digestion of brewery wastewater. Process Biochemistry 29: 645-650.

Chen Y, Cheng JJ and Creamer KS (2008) Inhibition of anaerobic digestion process: A review. Bioresource Technology 99: 4044-4064.

Connaughton S, Collins G and O'Flaherty V (2006) Psychrophilic and mesophilic anaerobic digestion of brewery effluent: A comparative study. Water Research 40: 2503-2510.

Cronin C and Lo KV (1998) Anaerobic treatment of brewery wastewater using UASB reactors seeded with activated sludge. Bioresource Technology 64: 33-38.

Fillaudeau L, Blanpain-Ave P and Daufin G (2006) Water, wastewater and waste management in brewing industries. Journal of Cleaner Production 14: 463-471. 


\section{Offprint provided courtesy of www.icevirtuallibrary.com Author copy for personal use, not for distribution}

Franklin RJ (2001) Full-scale experiences with anaerobic treatment of industrial wastewater. Water Science and Technology 44(8): 1-6.

Fuentes M, Scenna NJ and Aguirre PA (2011) A coupling model for EGSB bioreactors: Hydrodynamics and anaerobic digestion. Chemical Engineering and Process Intensification 50(3): 316-324.

Gonzalez JS, Rivera A, Borjab R and Unchez E (1998) Influence of organic volumetric loading rate, nutrient balance and alkalinity: COD ratio on the anaerobic sludge granulation of an UASB reactor treating sugar cane molasses. International Biodeterioration \& Biodegradation 41: 127-131.

Goodwin JAS, Finlayson JM and Low EW (2001) A further study of anaerobic biotreatment of malt whiskey distillery pot ale using an UASB system. Bioresource Technology 78: $155-160$

Kato MT, Rebac S and Lettinga G (1999) Anaerobic treatment of low-strength brewery wastewater in expanded granular sludge bed reactor. Applied Biochemistry and Biotechnology 76: 15-32.

Latif MA, Ghufran G, Wahid ZA and Ahmad A. (2011) Integrated application of upflow anaerobic sludge blanket reactor for the treatment of wastewaters. Water Research 45: 4683-4699.
Leal K, Chacin E, Behling E et al. (1998) A mesophilic digestion of brewery wastewater in an unheated anaerobic filter. Bioresource Technology 65: 51-55.

Lettinga G (1995) Anaerobic digestion and wastewater treatment systems. Antonie van Leeuwenhoek 67: 3-28.

Lettinga G, Hobma SW, Hulshoff Pol LW et al. (1983) Design, operation and recovery of anaerobic treatment. Water Science and Technology 15: 177-195.

Parawira W, Kudita I, Nyandoroh MG and Zvauya R (2005) A study of industrial anaerobic treatment of opaque beer brewery wastewater in a tropical climate using a full-scale UASB reactor seeded with activated sludge. Process Biochemistry 40: 593-599.

Van Der Merwe M and Britz TJ (1993) Anaerobic digestion of baker's yeast factory effluent using an anaerobic filter and a hybrid digester. Bioresource Technology 43: 169-174.

Zheng MX, Wang KJ, Zuo JE et al. (2012) Flow pattern analysis of a full-scale expanded granular sludge bed-type reactor under different organic loading rates. Bioresource Technology 107: $33-40$.

Zoutberg GR and de Been P (1997) The BIOBED ${ }^{\circledR}$ EGSB (Expanded Granular Sludge Bed) system covers shortcomings of the upflow anaerobic sludge reactor in the chemical industry. Water Science and Technology 35(10): 183-188.

\section{WHAT DO YOU THINK?}

To discuss this paper, please submit up to 500 words to the editor at journals@ice.org.uk. Your contribution will be forwarded to the author(s) for a reply and, if considered appropriate by the editorial panel, will be published as a discussion in a future issue of the journal. 